University of Nebraska - Lincoln

DigitalCommons@University of Nebraska - Lincoln

Papers in the Earth and Atmospheric Sciences

Earth and Atmospheric Sciences, Department

2000

\title{
Morphology and taxonomic position of the Late Cretaceous diatom genus Pomphodiscus Barker \& Meakin
}

Vladimir A. Nikolaev

Academy of Sciences of Russia

David M. Harwood

University of Nebraska-Lincoln, dharwood1@unl.edu

Follow this and additional works at: https://digitalcommons.unl.edu/geosciencefacpub

Part of the Earth Sciences Commons

Nikolaev, Vladimir A. and Harwood, David M., "Morphology and taxonomic position of the Late Cretaceous diatom genus Pomphodiscus Barker \& Meakin" (2000). Papers in the Earth and Atmospheric Sciences. 183.

https://digitalcommons.unl.edu/geosciencefacpub/183

This Article is brought to you for free and open access by the Earth and Atmospheric Sciences, Department of at DigitalCommons@University of Nebraska - Lincoln. It has been accepted for inclusion in Papers in the Earth and Atmospheric Sciences by an authorized administrator of DigitalCommons@University of Nebraska - Lincoln. 


\title{
Morphology and taxonomic position of the Late Cretaceous diatom genus Pomphodiscus Barker \& Meakin
}

\author{
Vladimir A. Nikolaev ${ }^{1}$ and David M. Harwood ${ }^{2}$ \\ ${ }^{1}$ Botanical Institute, The Academy of Sciences of Russia, Popova St. 2, St. Petersburg 197376 Russia \\ ${ }^{2}$ Department of Geosciences, University of Nebraska-Lincoln, Lincoln, NE 68588-0340 USA
}

\begin{abstract}
Results from our investigation of Upper Cretaceous diatoms from the Marca Shale Member of the Moreno Shale in California and from Ocean Drilling Program (ODP) Hole 748C on the Kerguelen Plateau, Southern Indian Ocean enable a clarification of the taxonomic position of several diatoms. Differences in areola structure, a primary and conservative character of the diatom valve, are used to separate diatoms recently included in the genus Benetorus. We resurrect the genus Pomphodiscus to include species with locular areolae, a central rimoportula, and a central inflated chamber. We propose the new species Pomphodiscus kerguelensis $\mathrm{n}$. sp. and new combination Pomphodiscus craspedodiscoides comb. nov.
\end{abstract}

\section{INTRODUCTION}

Sims (1994) studied the morphology of very rare Upper Cretaceous diatoms identified as Benetorus fantasmus Hanna (1927), Craspedodiscus morenoensis Long, Fuge \& Smith (1946), Coscinodiscus morenoensis var. sensu Long, Fuge \& Smith (1946) and Pomphodiscus morenoensis Barker \& Meakin (1946). All of these species were first reported from the upper Maastrichtian Moreno Shale of California. Subsequent occurrences of very rare specimens were reported from two Campanian samples from Core 82 on the eastern slope of the Ural Mountains (Strelnikova 1974). One specimen, similar to Coscinodiscus morenoensis var. sensu Long, Fuge \& Smith (1946), was described from Aptian? phosphorite near Hannover Germany and named Craspedodiscus incurvus by Forti and Schulz (1932).

Light microscope (LM) investigation identified characters common to all of these species. The central part of the valves possess a "sub-oval or pear-shaped depression" (Long, Fuge and Smith 1946, p. 105), or, a "large, shallow, sub-oval, blister-like punctate inflation" (Barker and Meakin 1946, p. 144). Forti and Schulz (1932) described and sketched Craspedodiscus incurvus with a circular central zone covered by small areolae in a radial array, in contrast to the larger areolae on the valve face. Benetorus Hanna appears in LM to have a similar structure; it was described by Hanna (1927, p. 15) as a "central circular area, hyaline at least in part and almost enclosing a pyriform beaded area in the center".

Sims (1994) examined (LM and SEM) these species in material from the Moreno Shale, including type material from Hanna (1927). In her paper, Sims provided a more accurate definition of valve structure, especially in the central part of the valve, where a central chamber is formed by the inflation and separation of two convex siliceous layers. The presence of a chamber was the main character used by Sims (1994) to combine the above species into the genus Benetorus and erect the new Family Benetoraceae.
This paper presents descriptions and illustrations of 3 species of the genus Pomophodiscus and one species of Benetorus. We describe their morphological structures and discuss their taxonomic positions.

\section{MATERIALS AND METHODS}

Upper Cretaceous material examined (SEM and LM) in this study includes sediment from California, Russia, and from the Kerguelen Plateau in the Southern Indian Ocean. Holotype material from the Marca Shale Member of the Moreno Shale (Hanna 1927; Long, Fuge and Smith 1946) was investigated by light microscopy. Two samples from Core 82, Ust'Manya, River Severnaya Sos'va, Tyumen'sk oblast were examined from the materials documented in Strelnikova (1974), but Craspedodiscus morenoensis was not encountered. Several samples from ODP Hole $748 \mathrm{C}$, between cores $42 \mathrm{R}$ to $57 \mathrm{R}$ (Schlich, Wise, et al. 1989) were prepared, but only sample ODP-748C-48R, $4-6 \mathrm{~cm}$ yielded diatoms in sufficient number and state of preservation to warrant detailed study. This sample contained a diversity of specimens of the genus Pomphodiscus. Diatom samples were taken from sediment within mollusk shells, which were treated chemically, as described in Harwood and Maruyama (1992).

LM examination and photomicrographs were performed on a Richart Polyvar microscope at the California Academy of Sciences and an Olympus $\mathrm{CH}-2$ with differential interference contrast (DIC) illumination at the University of Nebraska. Selection and orientation of diatom specimens for SEM investigation was done with a Narishige Model MN-15 micromanipulator from dry, clean material following the technology of Nikolaev (1982). A JOEL JSM-T330 SEM at the Department of Geosciences, University of Nebraska and a JOEL JSM-35 at the Botanical Institute, St. Petersburg were used to investigate morphological structures. 


\section{SYSTEMATIC PALEONTOLOGY}

\section{Division BACILLARIOPHYTA \\ Class CENTROPHYCEAE \\ Subclass COSCINODISCOPHYCIDAE \\ Order COSCINODISCALES \\ Family STELLARIMACEAE}

Genus Pomphodiscus Barker \& Meakin 1946

Frustule is discoid; valves are circular and weakly convex. An ovoid, circular chamber of different size is located at a central or sub-central position. The chamber is formed by an inflation and separation of the basal siliceous layer into two layers: (1) an outside domed layer, with an ovoid (tear-shaped) opening on the edge of the chamber, and (2) an inside, convex layer with a central or asymmetrical flexure and central depression. The valve margin is separated from the valve face by a low, hyaline ridge near the mantle. Locular areolae with a hexagonal/honeycomb form are arranged in radial rows and are sometimes weakly fasciculate. The external openings of the areolae are large and the internal opening is of small foramen that may be slightly thickened and sometimes possess a short spike that extends into and across the foramina. A single, central rimoportula with a wide external slit and a narrow interior slit is located at the point of maximum flexure on the inner layer of the chamber.

Generotype: Pomphodiscus morenoensis (Long, Fuge \& Smith) Barker \& Meakin 1946, p. 144, figs. 5, 6.

Age and distribution: Lower Cretaceous (Aptian?) Germany (Forti and Schultz 1932) to Upper Cretaceous of California (Long, Fuge and Smith 1946; Barker and Meakin 1946), Southern Indian Ocean (this report), South Pacific Ocean, DSDP Hole 275 (unpublished observation), and Polar Ural Mountains (Strelnikova 1974).

Pomphodiscus morenoensis (Long, Fuge \& Smith) Barker \& Meakin

Plate 1, figures 1-6; plate 2, figure 7
Craspedodiscus morenoensis LONG, FUGE \& SMITH 1946, p. 105, pl. 17, fig. 1.

Pomphodiscus morenoensis BARKER \& MEAKIN 1946, p. 144, figs. 5, 6.

Benetorus morenoensis (Long, Fuge \& Smith) SIMS 1994, p. 67, 169, figs. 7-12, 51, 56, 57.

Description: Valves are circular, $54-68 \mu \mathrm{m}$ in diameter and weakly convex with a small concavity around the central ovoid dome. A low marginal ridge is present between the valve mantle and the valve face. Loculate areolae are constructed with a large outside opening and small inside foramina; vela were not observed in studied materials. The areolae increase in size to the middle of the valve from both the margin and the edge of the chamber, with 7 areolae in $10 \mu \mathrm{m}$ at the valve margin, 6 areolae in $10 \mu \mathrm{m}$ at the middle of a row, and $8-10$ areolae in $10 \mu \mathrm{m}$ near central dome. Areolae are arranged in radial rows, 5-6 in $10 \mu \mathrm{m}$ in the row, and they form a weak fasciculate pattern. Valve mantle includes two rows of poroid areolae with 13-16 areolae in $10 \mu \mathrm{m}$. A single rimoportula is located near the valve center; the external opening is a wide slit with an irregular edge that is level with the external surface of valve (pl. 1, fig. 5). The internal opening of the rimoportula is a narrow slit, $3 \mu \mathrm{m}$ long with thin vertical lips, surrounded by a small hyaline field located near the central depression at the point of maximum flexure (pl. 1, fig. 6; pl. 2, fig. 7). The central part of the valve exterior is covered by an ovoid, sub-central siliceous layer (size of dome $15 \times 18 \mu \mathrm{m})$ with gentle relief and large sub-circular opening $(\sim 5 \mu \mathrm{m}$ in diameter) at the edge of the dome (pl. 1, fig. 2$)$. This opening narrows toward the center of the dome at the position of the rimoportular slit. The internal siliceous layer of this chamber is broadly convex to the inside of the valve, but has a minor central concavity with a slight flexure (pl. 1, fig. 6). Radial rows (11-15 in $10 \mu \mathrm{m})$ of pores are present on the chamber interior; 16 pores in $10 \mu \mathrm{m}$ along rows. Radial rows of foramen, which continue as pores on the central chamber across a narrow circular hyaline zone, change to pores on the inner layer of the central chamber. The external and internal layers of the central chamber are not in contact with one another, although a tube of the rimoportula crosses the central chamber.

PLATE 1

Pomphodiscus morenoensis, LM (figure 1), SEM (figures 2-6) of a single specimen. Marca Shale Member of the Moreno Shale, Fresno County, California, U.S.A. Scale bars $=10 \mu \mathrm{m}$ (figs. 1, 2, 6); $5 \mu \mathrm{m}$ (fig. 4); $1 \mu \mathrm{m}$ (figs. 3, 5).

1 Valve, holotype from Long, Fuge and Smith (1946) collection, Sample CAS 3402.

2 Valve exterior showing ornamentation of the central dome, the teardrop-shaped opening of the chamber, the slit-like opening of the rimoportula (arrow), radial rows of areolae on the valve face, the marginal ridge, and two rows of poroid areolae on the valve mantle.

3 Broken valves showing the structure of locular areolae with large external openings and small internal foramen.

4 Valve edge showing the marginal ridge and two rows of poroid areolae on the valve mantle.
5 Teardrop-shaped opening of the chamber (external view), showing the channel that connects the chamber to the elongate slit of the rimoportula (arrow). Ornamentation of the chamber include shallow pits on the external siliceous layer and pores of the internal siliceous layer are visible through the chamber opening.

6 Interior view of the valve showing the central dome with a depression and the rimoportula at the point of maximum depression (arrow). Radial rows of pores on the chamber cross a narrow hyaline zone and continue as radial rows of areolae on the valve. Two circular rows of foramina of poroid areolae are visible on the mantle. 

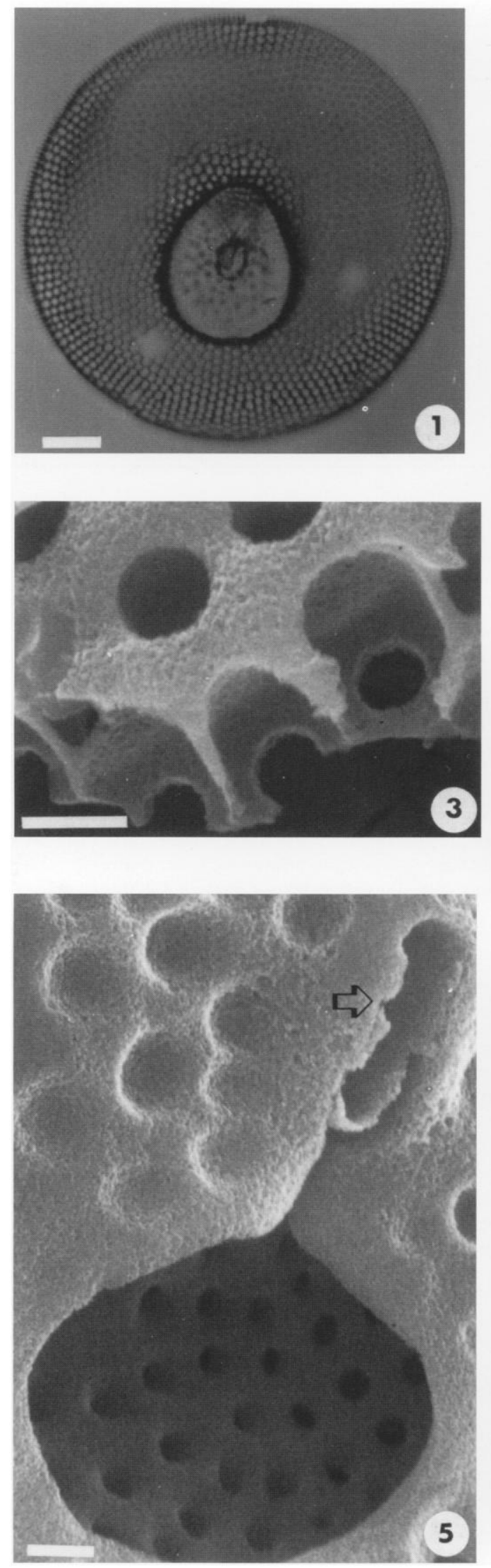
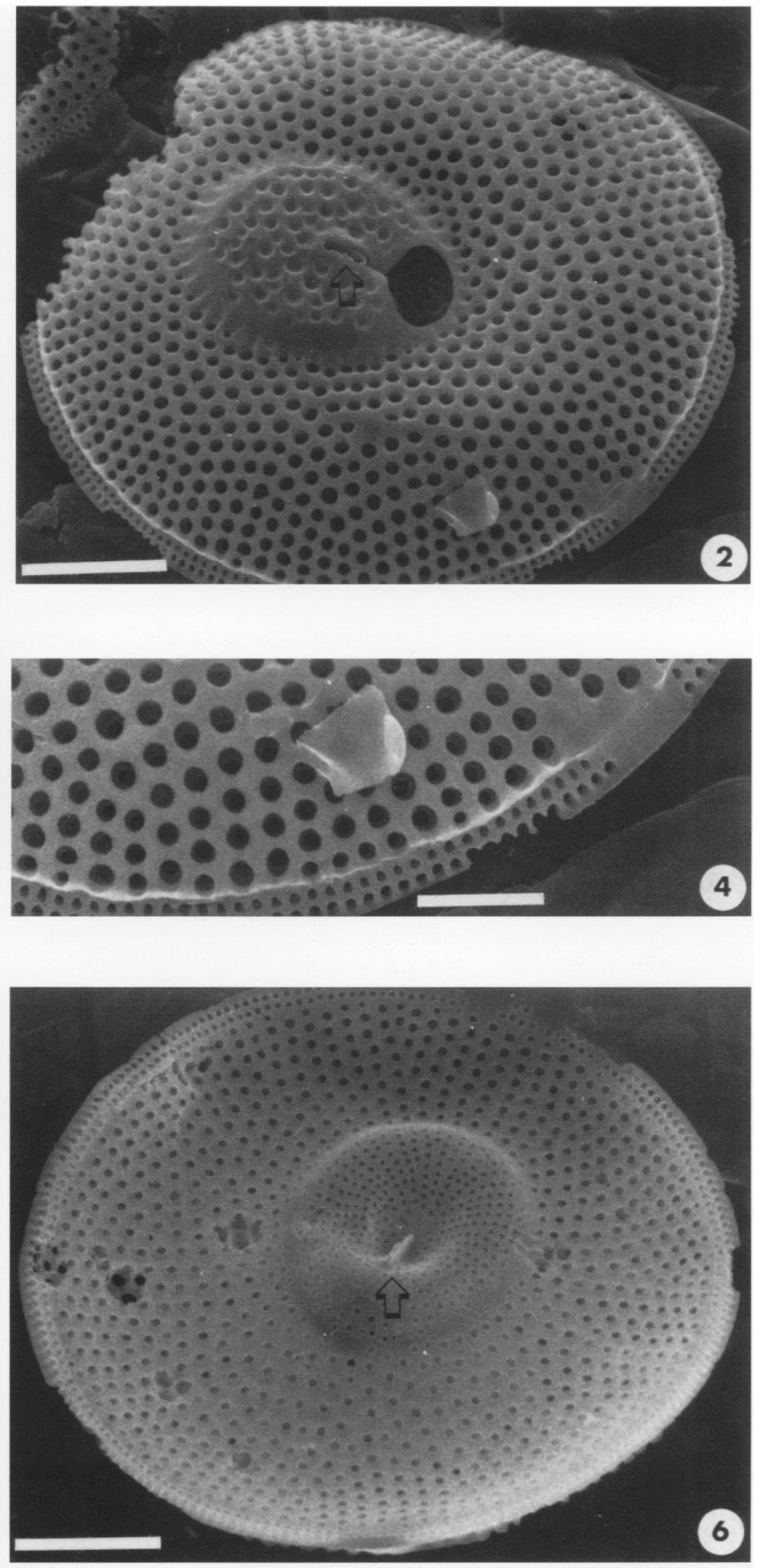
TABLE 1

Morphological comparison of genera.

\begin{tabular}{|c|c|c|c|c|c|}
\hline Genera & Valve & Areolae & Rimoportula & Central Chamber & Taxonomic Position \\
\hline Pomphodiscus & $\begin{array}{l}\text { Circular, weakly convex } \\
\text { central ovoid dome }\end{array}$ & $\begin{array}{l}\text { Locular; internal foramen in } \\
\text { radial rows; external cribra } \\
\text { not observed }\end{array}$ & $\begin{array}{l}\text { One central procoss crosses } \\
\text { the opening of the dome; extermal } \\
\text { wide silt; internal narrow slit }\end{array}$ & $\begin{array}{l}\text { Centralsurub-central extemal layer } \\
\text { without perforation; eccentric ovoid } \\
\text { opening; intermal radial rows of pores }\end{array}$ & $\begin{array}{l}\text { Order Coscinodiscales } \\
\text { Family Stollarimaceae }\end{array}$ \\
\hline Azpeitiopsis & $\begin{array}{l}\text { Circular, weakly convex } \\
\text { with small contral depression }\end{array}$ & $\begin{array}{l}\text { Locular; intemal foramen in } \\
\text { radial rows; external cribra } \\
\text { not observed }\end{array}$ & $\begin{array}{l}\text { One central process crosses the } \\
\text { depression; exterior wide slit; } \\
\text { interior long slit }\end{array}$ & not present & $\begin{array}{l}\text { Order Coscinodiscales } \\
\text { Family Stellarimaceae }\end{array}$ \\
\hline Stellarima & Circular, weakly convex & $\begin{array}{l}\text { Locular, internal foramen in } \\
\text { radial rows; external cribra }\end{array}$ & $\begin{array}{l}\text { One to six central processes in } \\
\text { radial orientation; extormal wide sitt, } \\
\text { internal short tube with wide slit }\end{array}$ & not present & $\begin{array}{l}\text { Order Coscinodiscales } \\
\text { Family Stellarimaceae }\end{array}$ \\
\hline Benetorus & $\begin{array}{l}\text { Approximately circular; } \\
\text { weakly convex; central } \\
\text { ovoid domed ring and } \\
\text { central depression }\end{array}$ & $\begin{array}{l}\text { Poroid; foramen intermal, } \\
\text { vola extemal; radial rows of } \\
\text { areolae divided by costa }\end{array}$ & $\begin{array}{l}\text { One contral process crosses } \\
\text { the central dome; extemal } \\
\text { round or short tube; internal } \\
\text { small slit }\end{array}$ & $\begin{array}{l}\text { Circular or chordate horseshoe- } \\
\text { shaped tunnel-form chamber } \\
\text { between the central dome } \\
\text { and areolate zone of valve face; } \\
\text { end of the unnel chamber } \\
\text { separated by a vertical wall }\end{array}$ & $\begin{array}{l}\text { Order Stictodiscales } \\
\text { Family Benetoraceae }\end{array}$ \\
\hline
\end{tabular}

Age and distribution: Upper Cretaceous (Maastrichtian); Marca Shale Member of the Moreno Shale, Moreno Gulch, Fresno Co., California (Long, Fuge and Smith 1946; Barker and Meakin 1946).

Remarks: SEM investigation was made on only one specimen from Hanna (1927) materials; CAS 610955.

Although Barker and Meakin (1946) did not formally transfer Craspedodiscus morenoensis (Long, Fuge \& Smith) to their new genus Pomphodiscus, they do state, "This form is... Craspedodiscus (C. morenoensis)...". We suggest that Barker and Meakin should be identified as having made this transfer. Barker and Meakin designated a new holotype, which we, and apparently Sims (1994), consider a junior synonym and paratype, in support of the holotype specimen of Long, Fuge and Smith (1946).

Pomphodiscus craspedodiscoides (Sims) Nikolaev \& Harwood nov. comb.

Plate 2, figures $8-14$, plate 3 , figure 15

Coscinodiscus morenoensis var. sensu LONG, FUGE \& SMITH 1946, p. 104, pl. 17, fig. 3; non Hanna (1927).

Benetorus craspedodiscoides SIMS 1994, p. 169, 171, figs. 13-20, 52.

Description: Valves are circular, $65-85 \mu \mathrm{m}$ diameter and weakly convex, with a concave ring around a central dome. A low marginal ridge is present between the valve mantle and the valve face. Loculate areolae contain a large external openings and a small internal foramina; vela were not observed in the examined

PLATE 2

7 Pomphodiscus morenoensis, SEM. Marca Shale Member. Scale bars $=1 \mu \mathrm{m}$. Internal view of the central part of the chamber showing the large slit of the rimoportula with vertical lips, a hyaline zone surrounding the rimoportula, and pores of the inner siliceous layer of the central chamber.

8-14 Pomphodiscus craspedodiscoides, LM (figures 8-10), SEM (figures 11-14). Kerguelen Plateau, Southern Indian Ocean, ODP Hole 748C-48R-1, 4-6cm. Scale bars $=10 \mu \mathrm{m}$ (figures 8-12, 14); $1 \mu \mathrm{m}$ (figure 13).

8,9 Valves at different focus $(8$ - focus on the external layer of the central chamber; 9 - focus on the internal layer of the central chamber). Rimoportula at the center of the chamber (arrows).
10 Valve with a large central chamber.

11,12 External view of valve showing the partly broken outer layer of the central chamber and radial rows of loculate areolae on the valve face. A marginal ridge is present between the valve face and mantle, which contains two rows of poroid areolae (arrow).

13,14 Internal view of the valve showing the internal dome with central depression. Radial rows of pores on the inner siliceous layer of the chamber cross a narrow hyaline ring and continue onto the valve as radial rows of foramen. Slit-like rimoportula (arrow). 

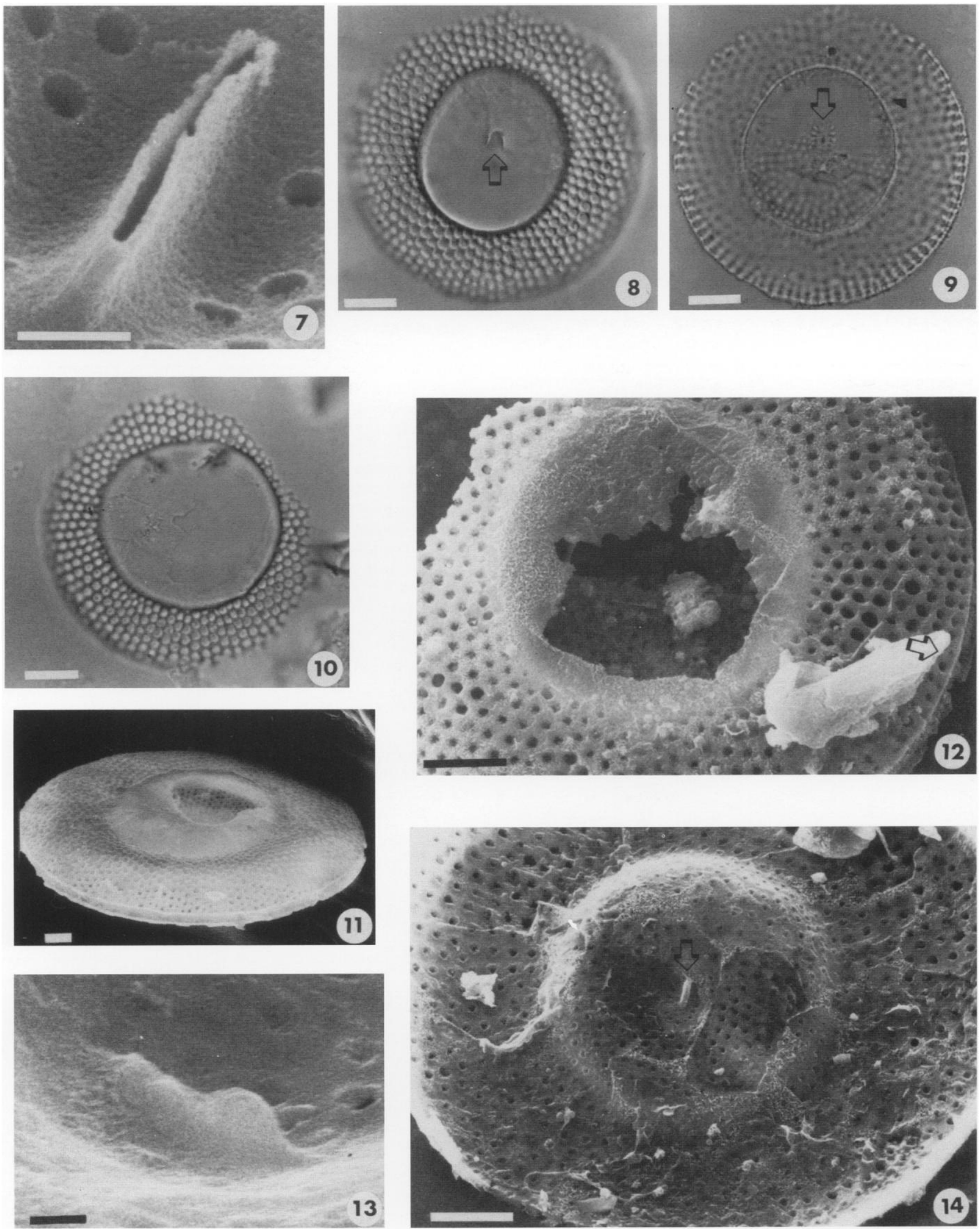
materials. The areolae increase in size toward the middle of the valve from both the margin and edge of the chamber: 4-6 areolae in $10 \mu \mathrm{m}$ at the valve mantle, $3-5$ in $10 \mu \mathrm{m}$ at the middle of the row, and 5-6 in 10 $\mathrm{m}$ near the central dome. Areolae are arranged in radial rows, with 4 areolae in $10 \mu \mathrm{m}$ in the row. The valve mantle is constructed with two rows of poroid areolae, $14-16$ in $10 \mu \mathrm{m}$. A single rimoportula is located near the valve center. The morphology of the rimoportula is an internal opening of a narrow slit, about $4 \mu \mathrm{m}$ long with vertical lips located near the central depression at point of maximum flexure and ssurrounded by a small hyaline field (pl. 3, fig. 15). The external opening of the rimoportula is unknown (usually broken), but probably is a large slit. The central part of the valve, from $1 / 3$ to $2 / 3$ diameter of the valve is covered on the outside by a circular domed, siliceous hyaline layer, with a large teardrop-shaped opening near the edge of the dome. The internal siliceous layer of the central chamber is convex toward the inside of the valve, with a linear depression. Radial rows (6-7 in $10 \mu \mathrm{m}$ ) of pores, 6-7 pores in $10 \mu \mathrm{m}$ are arranged along rows. Radial rows of foramen continue to the center of the chamber, without crossing a hyaline zone, and continue on the central chamber as pores. External and internal layers of the central chamber are not in contact.

Age and distribution: Rare, Upper Cretaceous (Maastrichtian); Marca Shale Member of the Moreno Shale, Moreno Gulch, Fresno Co., California (Long, Fuge and Smith 1946); Frequent, Upper Cretaceous (upper Campanian-lower Maastrichtian), Kerguelen Plateau, ODP Hole 748C-48R-1.

Remarks: There is considerable variability in the size of the valve and of the central chamber in specimens from Kerguelen Plateau. The size of the valves, the areolae and the form and size of the central chamber is similar to that of Craspedodiscus incurvus Forti \& Schulz (1932, p. 241, text figure 1). These two species are probably closely related. SEM investigation of Craspedodiscus incurvus from similar age material is needed in order to demonstrate the character of the central region and the central process. Forti and Schulz (1932) do not indicate the presence of a process in their line drawing of this species. We believe $C$. incurvus belongs within, or close to, Pomphodiscus, but we await observations of the central process by SEM before proposing a transfer.

\section{Pomphodiscus kerguelensis Nikolaev \& Harwood n. sp.} Plate 3, figures 16-19

Derivation of name: Named for the submarine Kerguelen Plateau, where this taxon was first encountered.

Holotype: Deposited in the G Dallas Hanna Diatom Collection CAS\# 21609; California Academy of Sciences; Kerguelen Plateau, southeast Indian Ocean, ODP Hole 748C-48R-1, 4-6cm, upper Campanian-lower Maastrichtian. Holotype - Plate 3, figure 16.

Description: Frustule discoidal. Valves are circular $(45-57 \mu \mathrm{m}$ diameter) and convex with an ovoid concavity around a weakly convex central dome. A low marginal ridge lies between the valve face and mantle. Areolae are loculate, and are constructed with a large outside opening and small inside foramina; vela were not observed in investigated material. The areolae are nearly equal in size across the valve, $8-10$ in $10 \mu \mathrm{m}$ to the middle

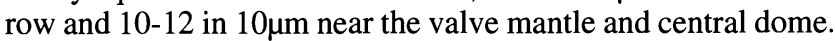
Areolae are arranged in radial rows, $9-10$ in $10 \mu \mathrm{m}$ in the row. The structure of the valve mantle is unknown. A single rimoportula is located in the valve center. The central chamber of the epitheca and hypotheca are covered on the outside by an ovoid, almost central, weakly convex siliceous layer (of size 10 by $17 \mu \mathrm{m})$, which has a teardrop-shaped opening orientated in opposing direction on the two valves of the frustule (pl. 3, fig. 17). The internal siliceous layer of the central chamber is convex toward the inside of the valve, and the central concavity has a slight flexure. Pores $(18$ in $10 \mu \mathrm{m})$ are arranged in radial rows that are spaced $18-20$ in $10 \mu \mathrm{m}$. Radial rows of foramen continue toward the central chamber, crossing a circular hyaline-ring, and continuing as pores on the central chamber.

Age and distribution: Rare, Upper Cretaceous (Upper Campanian-Lower Maastrichtian), Kerguelen Plateau, ODP Hole
15 Pomphodiscus craspedodiscoides, SEM. Kerguelen Plateau, Southern Indian Ocean, ODP Hole $748 \mathrm{C}-48 \mathrm{R}-1,4-6 \mathrm{~cm}$. Scale bars $=10 \mu \mathrm{m}$. View of valve interior showing radial rows of pores on the central chamber that continue as radial rows of foramen on the valve face toward the mantle. Rimoportula (arrow) is located in the central depression on the chamber, at the site of maximum flexure.

16-19 Pomphodiscus kerguelensis, LM (figs. 16-17), SEM (figs. 18-19). Kerguelen Plateau, Southern Indian Ocean, ODP Hole 748C-48R-1, 4-6 cm. Scale bars = $10 \mu \mathrm{m}$ (figs. 16-18); $5 \mu \mathrm{m}$ (fig. 19).

16 Holotype, CAS \#21609 deposited in the California Academy of Sciences. Valve with radial rows of areolae, central chamber with rimoportula (arrow).
17 Frustule with slightly separated epitheca and hypotheca, both with central chambers. Focus is on the central chamber and rimoportula (arrow).

18 Valve exterior showing the central ovoid dome with a tear-shaped opening that includes a narrow extension toward the position of the rimoportula. Radial rows of locular areolae are present on the valve face.

19 View of the central area of the valve interior showing the central dome with slight depression and radial rows of pores, which continue across a hyaline zone as rows of foramen on the valve margin.

20 Benetorus fantasmus, holotype of Hanna (1927) CAS \# 2000, LM. Moreno Shale, Fresno Co. California, U.S.A. scale bar $=10 \mu \mathrm{m}$. 

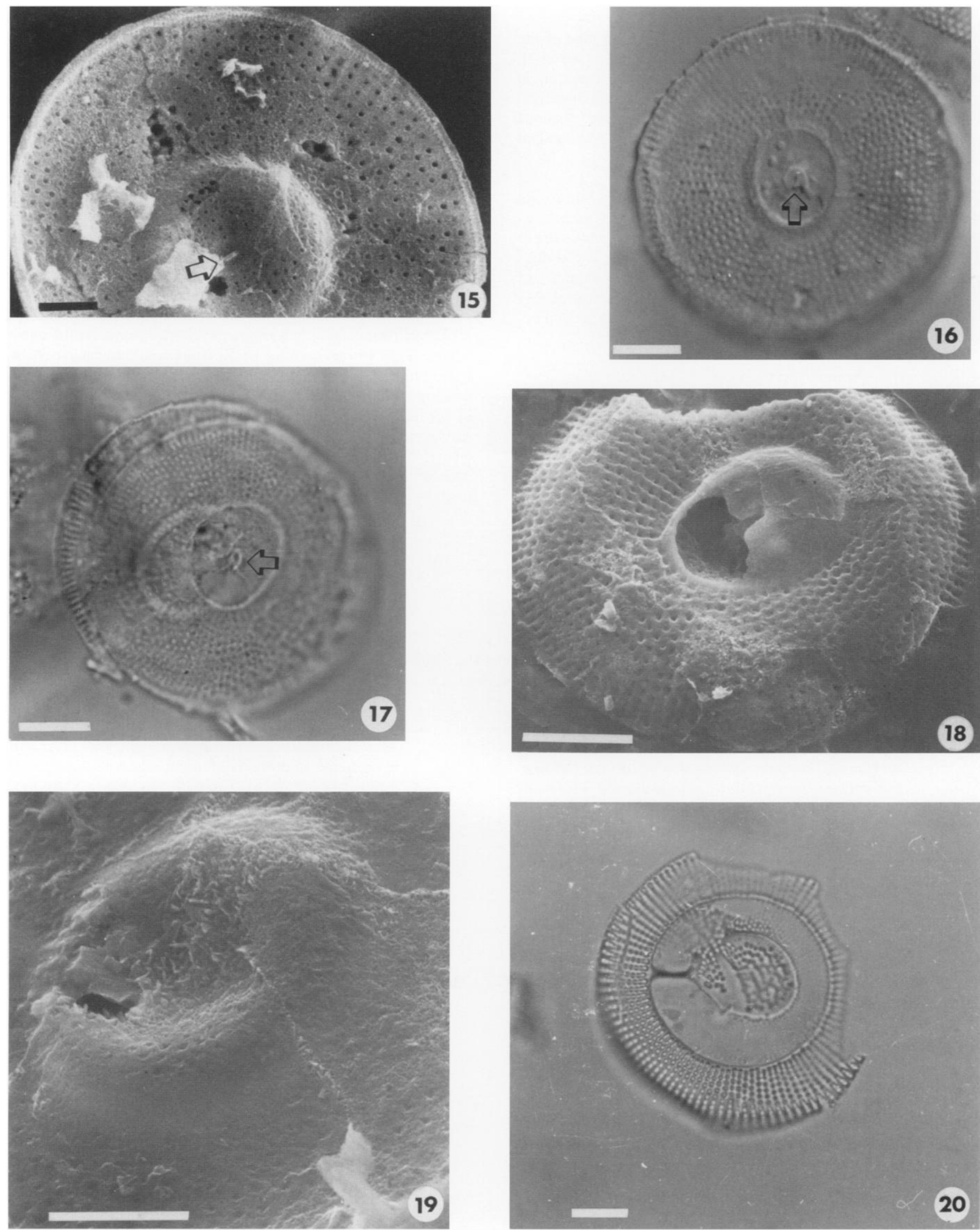
748C- 48R-1; possibly Southwest Pacific Ocean, DSDP Hole 275-2-1, 130-132cm (Hajós and Stradner 1975).

Remarks: The areolae are of small size, resembling that of the spores of Stellarima steynyi, which is common in this material, but lacks the central chamber of Pomphodiscus. Rimoportulae were not observed in the SEM on the internal or external valves, but the large slit-form opening on the outside of the siliceous layer may mark the position of the rimoportula as documented in light micrographs (pl. 3, figs. 16, 17).

Hajós and Stradner (1975, Plate 19, fig. 6) identify but do not discuss a specimen they identified as Benetorus fantasmus Hanna. This specimen bears strong similarity to Pomphodiscus kerguelensis, particularly the fine areolar structure, and it does not possess the central chamber with the "isthmus" of Benetorus fantasmus. For these reasons we believe it probably is a specimen of $P$. kerguelensis, and may represent a second occurrence of this taxon in the Southern Hemisphere.

\section{Subclass BIDDULPHIOPHYCIDAE Order STICTODISCALES Family STICTODISCACEAE}

Genus Benetorus Hanna 1927

Description: A description of this genus is not presented here, because the description of Sims (1994) is of sufficient detail.
Benetorus fantasmus Hanna

Plate 3, figure 20, plate 4, figures 21-28

Benetorus fantasmus HANNA 1927, p. 16, pl. 1, figures 9, 10; SIMS 1994, p. 166-167, figures 1-6, 49, 50, 54, 55.

Description: Frustule unknown, probably heterovalvar in the form of the central chamber convexity. Valves approximately circular (40-55 $\mu \mathrm{m}$ diameter), weakly convex, with a small concavity around a circular or cordate central dome, with an ovoid central depression. Low marginal ribs are present between the valve mantle and the valve face. Areolae are poroid with small external vola. Size of the areolae increases slightly from the mantle to the central chamber. Radial rows of areolae are divided by low costae. Within these rows, there are 8 areolae in $10 \mu \mathrm{m}$ at the valve mantle, $10-11$ in $10 \mu \mathrm{m}$ in the middle of a row, and 11-16 areolae in 10 $\mu \mathrm{m}$ near center of the chamber. The valve mantle possesses one row of elongate poroid areolae $(16-22$ in $10 \mu \mathrm{m})$. A single rimoportula is located near the valve center. The external opening of the rimoportula is round or with a short tube. The internal opening is a short slit with small lips, surrounded by a large irregular hyaline zone. Two narrow slits in the basal siliceous layers are present to one edge of the rimoportula. The central part of the valve, from $1 / 2$ to $2 / 3$ diameter, is covered on the outside by a nearly circular or cordate, domed siliceous layer, with an ovoid depression and irregular (usually broken) opening near the edge of the dome. The center

\section{PLATE 4}

Benetorus fantasmus. SEM. Marca Shale Member of the Moreno Shale, Fresno Co. California, U.S.A. Scale bars $=10 \mu \mathrm{m}$ (figs. 21, 22, 27); $5 \mu \mathrm{m}$ (fig. 25); $1 \mu \mathrm{m}$ (figs. 23, 24, 28); 0.5 $\mu \mathrm{m}$ (fig. 26). 21-25, Valve exterior.

21 View of valve exterior showing radial rows of areolae between ribs on the valve face. Tunnel-shape chamber is separated from the areolated zone by an ovoid central depression. A convex central region within the ovoid depression is covered by irregular shallow pits and sparse pores. The closed tube of the rimoportula is located at the junction of the tunnel-chamber and the central dome and marked by an arrow (see detail in figure 24).

22 View of external valve showing the chordate tunnel-shaped chamber with a broken edge, and outer zone of radial rows of poroid areolae. The marginal ridge separates one circular row of elongate poroid areolae on the valve mantle. Details of this specimen shown in figures 23,25 and 26.

23 Details of mantle structures of two valves. One row of elongate areolae at mantle, and rows of poroid areolae between costae (left) on the upper valve. Lower valve shows the foramen and broken wall of the tunnel-chamber (right).

24 Closed tube of rimoportula (enlarged view of figure 21).
25 External view of central part of the valve. In this specimen the broken external hyaline siliceous layer surrounds the underlying internal siliceous layer, with irregular pores (also visible in 'shadows'). Short tube of the rimoportula (arrow) is visible on the internal surface of the lower layer. Note the close contact of the inner surfaces of the two siliceous layers that form the chamber.

26 Detail of a broken valve showing the poroid areolae with vola (arrow).

27 Internal view of the valve showing the structure of the central region. Cordate central part of the valve with radial rows of pores on the inner siliceous layer of the chamber. Central hyaline zone with a slit form of the rimoportula. Horseshoe-shaped tunnel chamber is formed between the valve center and the areolate zone of the valve face. The chamber is partitioned by a vertical hyaline wall ("isthmus" of Hanna, 1927)(arrow). Radial rows of pores on the chamber are separated from areolar rows by a vertical hyaline ring. Mantle possesses one circular row of small foramen.

28 Detail of central region from figure 27. Central hyaline zone with a slit form of the rimoportula and two narrow slits through the basal siliceous layer, near the edge of the rimoportula. 

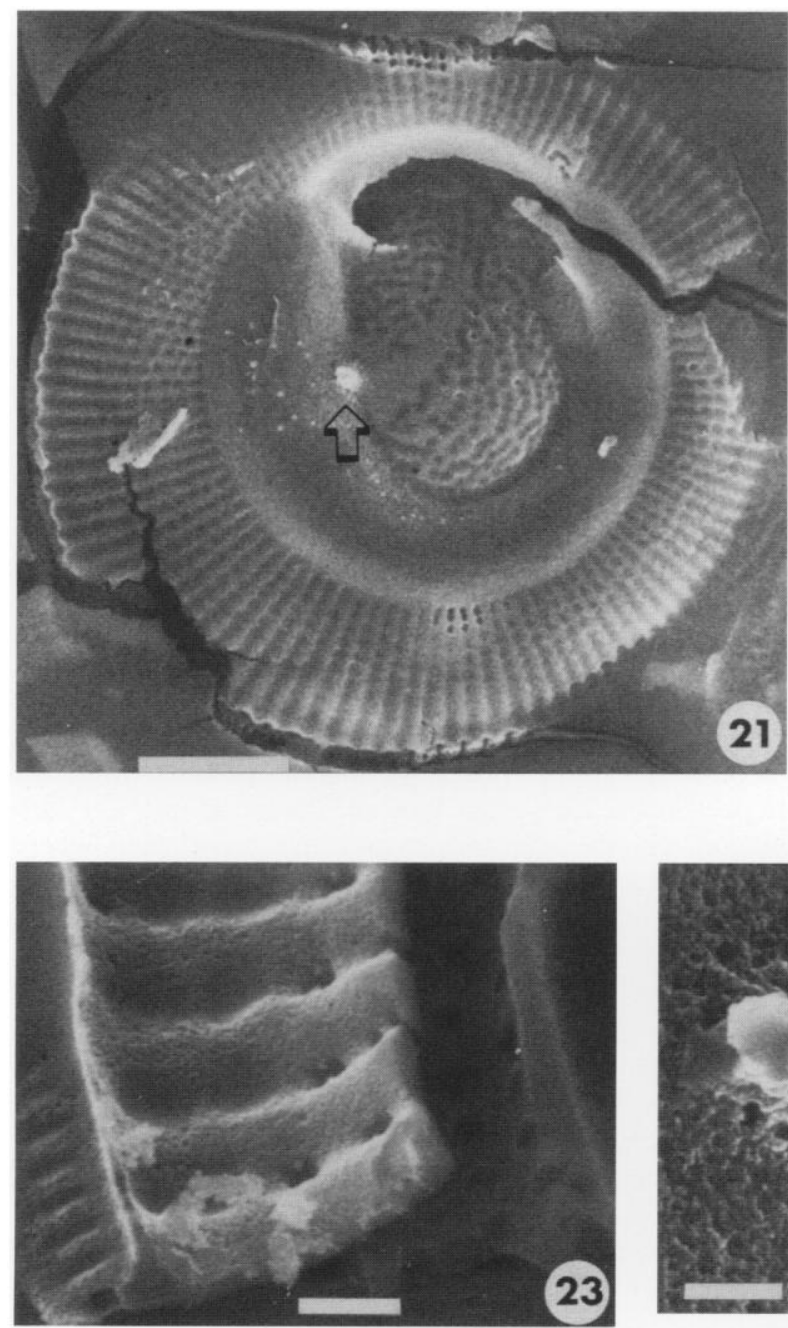

23
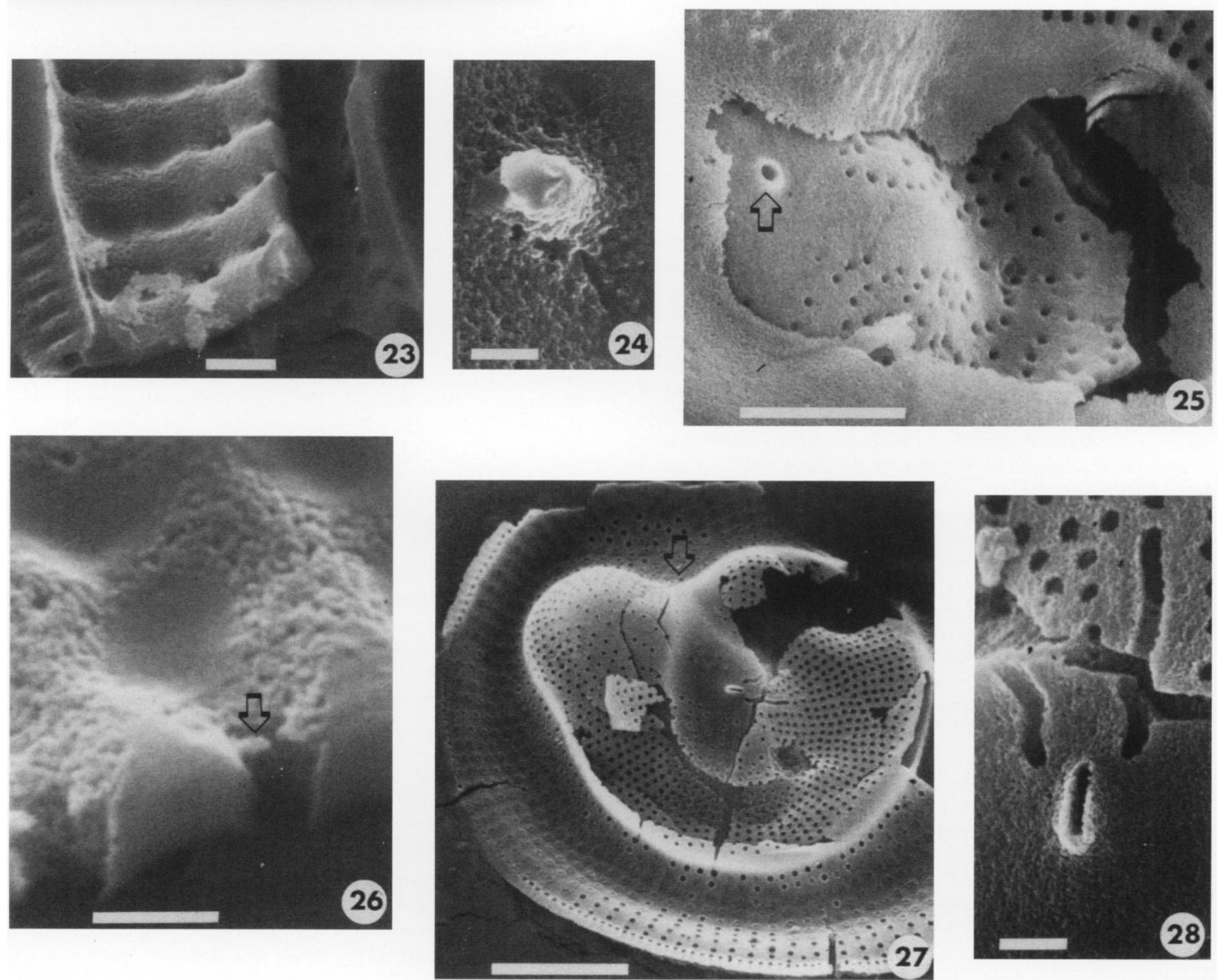
of the valve may posses an ovoid, slightly domed region covered by an irregular distribution of shallow pits, some of which are open pores. The internal siliceous layer of the chamber is convex, with a small central depression and radial rows of pores of irregular spacing, length and sometimes direction (14-16 rows in $10 \mu \mathrm{m}$ with 16 pores in $10 \mu \mathrm{m}$ in each row). Radial rows of foramen continue toward the valve center across a vertical, narrow hyaline zone. The external and internal siliceous layers are in contact at the valve center. A horseshoe-shaped tunnel chamber is formed between the valve center and the areolate zone of the valve face. This chamber is interrupted by a vertical hyaline wall ("isthmus" of Hanna, 1927) formed by the connection of the outside and inside siliceous layers. This linear connection of the two layers continues to the valve center.

Age and distribution: Upper Cretaceous (Maastrichtian); Marca Shale Member of the Moreno Shale, Moreno Gulch, Fresno County, California (Hanna 1927).

Remarks: SEM investigation was made on two specimens of this rare diatom. One specimen was probably from a very thin frustule, the broken edge of which shows the two layers of the central chamber in juxtaposition and the short tube of the rimoportula in the center (pl. 4, figs. 22, 25). Another specimen (pl. 4, fig. 21) is different from other specimens of this species (including that in Sims 1994) by: (1) the structure of the central dome, which is a nearly circular, tunnel chamber; (2) by the presence of a short external tube (closed) of the rimoportula; and (3) by the location of the rimoportula at the inner margin of the tunnel-chamber, rather than at the center.

\section{DISCUSSION}

Proshkina-Lavrenko $(1974$, p. 899$)$, in a survey of early investigations using the electron-microscope to examine diatom algae suggested that, "the fine-structure indicates the character of perforations of the frustule, which is closely connected with the physiology of the cell and its metabolism with the environment: it indicates the genetic relationship". This fundamental framework guided revisions of the diatom system by Gleser (1979 1985, 1986), Gleser et al. (1988), Nikolaev (1984a, 1984b, 1990), Harwood and Nikolaev (1995) and in part, it directed the systems of Simonsen (1979) and Round et al. (1990). The structure of areolae is the main character used to divide diatoms of high taxonomic rank. This approach has relevance to the present discussion, as it distinguishes taxa of the Order Coscinodiscales, which have locular areolae, from those of the Order Stictodiscales, which have poroid areolae (Table 1).

This theoretical approach to understand diatom phylogeny indicates a clear difference between the genera Benetorus and Pomphodiscus. Benetorus fantasmus has poroid areolae with volae (pl. 4, figs. 23, 26). The rows of areolae are separated by hyaline ribs (pl. 4, fig. 22, 23), which resemble the "hyaline line somewhat as in Stictodiscus", as mentioned by Hanna (1927, p. 16) in the original description of Benetorus. All known specimens of Pomphodiscus have locular areolae with a "honeycomb" chamber, and as shown by Sims (1994), have a velum on the outside of the valve.

The central chamber of Benetorus has a ring-form chamber, resulting from the contact of the two layers of the central part of the chamber. The tube of the central rimoportula penetrates these two layers at their point of connection (pl. 4, figs. 24, 25). The ring-form chamber is partitioned by a thin vertical siliceous wall (pl. 3, fig. 20; pl. 4, fig. 27); this is described as an "isth- mus" by Hanna (1927). The two layers of the central chamber of Pomphodiscus are not connected at the center as in Benetorus, but are crossed by the tube of the rimoportula.

The internal (slit) and external (circular) openings of the rimoportula in Benetorus fantasmus are different. The rimoportula of Pomphodiscus spp. is constructed with slits on both the inside and outside of the valve, or rimoportula with two slits (Nikolaev 1983), similar to diatoms in the Family Stellarimaceae.

The only characters that are common to both of these genera are: (1) central position of the rimoportula; (2) chambers with an external opening; and (3) similar position and form of the marginal hyaline ridge, which separates the valve mantle from the valve face. These common characters do not offer good evidence for a genetic connection between Benetorus and Pomphodiscus.

Available paleontological evidence suggests that Benetorus fantasmus may be endemic to the Upper Cretaceous of California. Pomphodiscus craspedodiscoides has a wider distribution, as indicated by its rare occurrence in California and abundant occurrence on the Kerguelen Plateau. Pomphodiscus kerguelensis occurs with the latter species on Kerguelen Plateau, where it is rare. Hajós and Stradner (1975) illustrate a specimen which may be $P$. kerguelensis from DSDP Site 275 in the South Pacific Ocean.

The composite of the genera Pomphodiscus, Azpeitiopsis and Stellarima, which possess similar morphological features (Table 1), occur together in many deposits. The only morphological feature that separates Pomphodiscus from these other two genera is the presence of a central chamber.

Craspedodiscus incurvus Forti \& Schulz 1932 and Craspedodiscus morenoensis sensu Strelnikova (1974) probably belong within the genus Pomphodiscus. If so, the age and distribution of species of Pomphodiscus will span a broader temporal range (Lower to Upper Cretaceous) and spatial range (in both $\mathrm{N}$ and $\mathrm{S}$ hemispheres). SEM investigation of these species is required before this transfer can occur, because, as shown by our unpublished investigation of Californian materials, a similar central chamber (internal view) also occurs in a species of Aulacodiscus.

If Azpeitiopsis and Pomphodiscus are removed from the Family Benetoraceae, as we propose, then the taxonomic position of Benetorus sensu Hanna (1927) is clearly within the new Family Benetoraceae Sims (1994). Sims' (1994) placement of this family near the Family Stellarimaceae is suspect, as the morphological criteria presented here indicate a more comfortable position of Benetoraceae within the Order Stictodiscales, near the Family Stictodiscaceae. Hanna (1927) twice suggested this connection to Stictodiscus.

We believe the position of Azpeitiopsis Sims (1994) is unclear. Sims assumes a position of Azpeitiopsis near the genus Azpeitia Peragallo, by the presence of a central rimoportula in both genera. However, members of the genus Azpeitia possess a marginal ring of rimoportulae and one sub-central rimoportula. The absence of this marginal ring of rimoportulae in Azpeitiopsis may indicate a position closer to the genus Pomphodiscus, which has only one rimoportula, in a central position. 
The taxonomic position of the genus Pomphodiscus is more clear. Comparison of morphological attributes between species of Pomphodiscus and Stellarima suggests these taxa are closely related. They all share locular areolae and a central rimoportula, and both Pomphodiscus and Stellarima have external and interior slits of the rimoportula. On the basis of these shared characters, these taxa, and possibly also Azpeitiopsis, are best placed within the Family Stellarimaceae.

\section{ACKNOWLEDGMENTS}

SEM photomicrographs were prepared by the skillful hands of Diane Winter; we acknowledge and thank her for her efforts. Pedro Tapia aided with laboratory preparation of Kerguelen Plateau materials. Pat Kociolek provided sample materials from the G Dallas Hanna Collection. N. Strelnikova provided materials for this investigation from the Polar Urals, Russia. We thank P.A. Sims for sharing with us an early print of her paper and for helpful discussion. P. Kociolek and J. Barron provided valuable comments in review of an early draft. A. Gombos and R. Gersonde reviewed this paper. This research was supported by NSF grant DPP-9158075 to DMH and by the alumni of the Department of Geosciences, University of Nebraska-Lincoln.

\section{REFERENCES}

BARKER, I. W. and MEAKIN, S. H., 1946. New diatoms from the Moreno Shale. Journal of the Quekett Microscopical Club, series 4 (2): 143-144.

FORTI, A. and SCHULZ, P., 1932. Erste Mitteilung über Diatomeen aus dem Hannoverschen Gault. Beihefte zum Botanische. Centralblatt., 50: 241-246.

GLESER, Z.I., 1979. Evolution and systematics of the Order Biddulphiales (Bacillariophyta). Paleontological Journal, 1: 110-120. (In Russian)

, 1985. Outline of a new classification of diatomaceous algae. In: Aktual'nie voprosi sovremennoi paleoal'gologii. Kiev. NAUK DUMKA: 65-69. (In Russian)

1986. Phylogeny of diatoms in the Order Coscinodiscales and preliminaries of a new classification. Edgegodnik vsesouznogo paleontologicheskogo obsczestva, 29: 180-187. (In Russian)

GLESER, Z.I., MAKAROVA, I.V., MOSSEVA, A.I. and NIKOLAEV, V.A., 1988. The diatoms of the U.S.S.R. Fossil and Recent, vol. 2, pt. 1, 114 pp., 60 pls. NAUKA, Leningrad. (In Russian)

HANNA, G D., 1927. Cretaceous diatoms from California. Occasional Paper of the California Academy of Sciences, 13: 5-49.

HAJÓS, M. and STRADNER, H., 1975. Late Cretaceous Archaeomonadaceae, Diatomaceae, and Silicoflagellatae from the South Pacific Ocean, Deep Sea Drilling Project, Leg 29, Site 275. In: Kennett, J. P., Houtz, R.E., et al., Eds., Initial Reports of the Deep Sea Drilling
Project, volume 29: 913-1109. Washington, DC: US Government Printing Office.

HARWOOD, D. M. and MARUYAMA, T., 1992. Middle Eocene to Pleistocene diatom biostratigraphy of ODP Leg 120, Kerguelen Plateau. In: Proceedings of the Ocean Drilling Program, Scientific Results, Leg 120, pp. 683 -733. College Station, TX: Ocean Drilling Program.

HARWOOD, D. M. and NIKOLAEV, V. A., 1995. Cretaceous diatoms: morphology, taxonomy, biostratigraphy. In: Blome, C. D., Whalen, P. M. and Reed, K. M., Convenors, Siliceous Microfossils. Paleontological Society Short Courses in Paleontology, 8: 81-106.

LONG, J. A., FUGE, D. P. and J. SMITH, 1946. Diatoms of the Moreno Shale. Journal of Paleontology, 20 (2): 89-118.

NIKOLAEV, V.A., 1982. Contribution to the method of preparing diatom algae for the light and scanning electron microscope. Botanicheskii Zhurnal, 67 (12): 1677-1680. (In Russian)

, 1984a. On the importance of the areolae structure for taxonomy of diatoms (Bacillariophyta). Botanicheskii Zhurnal, 69 (8): 1040-1046. (In Russian).

1984b. To the construction of the system of diatoms (Bacillariophyta). Botanicheskii Zhurnal, 69 (11): 1468-1474. (In Russian)

, 1990. The system of centric diatoms. In: Simola, H. , Ed., Proceedings of the 10th International Diatom Symposium. Koeltz Scientific Publications, pp. 17-24.

1993. The "pore" apparatus of centric diatoms: description of terms. Beihefte, Nova Hedwigia, 106: 33-42.

PROSCHKINA-LAVRENKO, A. I., 1974. On the taxonomy of diatoms (Bacillariophyta). Botanicheskii Zhurnal, 59 (6): 895-901. (In Russian)

ROUND, F. E., CRAWFORD, R. M., and MANN, D. M., 1990. The diatoms, biology and morphology of the genera. 747 pp. Cambridge: Cambridge University Press.

SCHLICH, R., WISE, S.W., Jr. and ODP Leg 120 Shipboard Scientific Party. Site 748. In: Schlich, R., Wise, S.W., Jr., et al. Proceedings of the Ocean Drilling Program, Initial Reports, volume 120:156-236. College Station, TX: Ocean Drilling Program.

SIMS, P.A., 1994. Benetorus, Gladiopsis and related genera from the Cretaceous. Diatom Research, 9 (1): 165-187.

SIMONSEN, R., 1979. The diatom system: ideas on phylogeny. Bacillaria, 2: 9-71.

STRELNIKOVA, N. I., 1974. Diatomei pozdnego mela (Late Cretaceous diatoms of western Siberia): NAUKA, Moscow. 203 pp.

Manuscript received April 25, 1995

Revised manuscript accepted April 15, 1999 